\title{
Chromosome Numbers of Cultivated Plants III. ${ }^{1}$
}

\author{
By
}

\section{T. Morinaga and E. Fukushima}

Received February 3, 1931.

Excepting Oryza sativa, L., which was examined by the ironacetocarmine method, the following observations were made exclusively on permanent preparations made by the paraffin method. BENDA's, BouIn's and CARNOY's fixatives were used in this work.

All figures are drawn with the aid of ABBE's large drawing apparatus under the use of a Zeiss apochromatic objective $1.5 \mathrm{~mm}$. and compensation ocular 18. The magnification is 2,000. Figures with $\times$ are reduced to two-thirds of their original size.

Sagittaria trifolia, L. var. sinensis, MaKINO (Alismac.) $\mathrm{n}=11,2 \mathrm{n}=22$.

The chromosome number of this plant was determined as twenty in diploid by Nawa. We however, counted, very clearly twentytwo long chromosomes in the root-tip cells. Two chromosomes, nearly twice as long as others, are attached by the spindle-fiber at the middle. Among the rest twenty chromosomes, eighteen are inserted by the fiber at the end, while the remaining two are attached by it at subterminal points (Fig. 1). Also eleven chromosomes were found in the heterotypic metaphase of the pollen mother-cell (Fig. 2).

Oryza sativa, L. (Gramin.) $\mathrm{n}=12$.

The number of chromosomes of the rice plant was reported as twelve by KuwadA and Naratomi. The following cultivated races were ascertained by us to have the same reduced number of chromosomes.

\footnotetext{
Names of races.

Muyôzetu-tô

2 Bonsti-tô

3 Nagakuki-daikoku

4 Tyôryû-moti

5 Hunın-sankaku-tô

6 Hunten-tô
}

$\begin{array}{cc}\text { Sources of the seeds. } & \text { n. } \\ \text { Japan proper } & 12 \\ \text { " } & \text { " } \\ \text { " } & \text { " } \\ \text { " } & \text { " } \\ \text { " } & \text { " }\end{array}$

1. Contributions from the Institute of Agronomy, Kyushu Imperial University, No. 30. 
7 Sinriki-husoroi-tô

8 So-hunen-tô

9 'Tai-tô

10 Kame-no-o

11 Ôno-Wase

12 Ebi-mai

13 Heitai

14 Ukoku

15 Seiyu

15 Odaziro

17 Kô-tô

18 Tikuson

19 Sen-tô

20 Hondurus

21 Vintula

22 Dady wrigh

23 Blue-rose

24 Suda balawi

25 (Name unknown)

26 Tyûtô-Sinriki $\times$ Kôketu-moti $F_{1}$

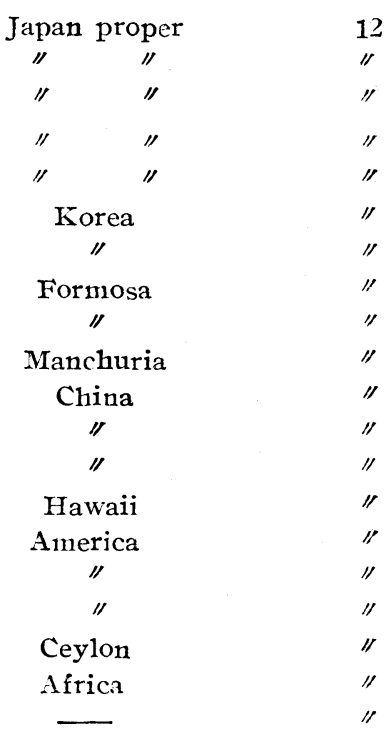

Scirpus mucronatus, L. (Cyperac.) $\mathrm{n}=21$.

Twenty-one small chromosomes were clearly counted in the homotypic metaphase of the pollen mother-cell (Fig. 3).

Monochoria vaginalis, PRESL. (Pontederiac.) $\mathrm{n}=26$.

Fig. 4 shows twenty-six spherical chromosomes of various sizes, which we observed clearly in the heterotypic metaphase of the pollen mother-cell.

Allium Scorodoprasum, L. var. viviparum, REGEL. (Liliac.) $\mathrm{n}=\mathrm{S}$, $2 \mathrm{n}=16$.

KATAYAMA reported sixteen as the diploid number of chromosomes. We found eight chromosomes in both meiotic division metaphases (Fig. 5, heterotypic metaphase). Also sixteen long chromosomes were observed in the root-tip cells. The spindlefiber attachment is either median or submedian (Fig. 6).

Allium fistulosum, L. var. caespitosum, Makino (Liliac.) $2 \mathrm{n}=16$.

The haploid chromosome number of this plant was determined as eight by Hirata and Akihama. Sixteen long chromosomes of median or submedian spindle-fiber attachment were found by us in the root-tip cells. A satellite like body was noticed as shown in Fig. 7.

Allium nipponicum, Franch. et SAv. (Liliac.) $2 \mathrm{n}=32$.

KaTAYAMA reported eight as the haploid number of chromosomes. The materials examined by us contained thirty-two long chromosomes in the root-tip cells. The spindle-fiber attachment is 
median, submedian or subterminal (Fig. 8).

Allium Bakeri, REGEL. (Liliac.) $2 \mathrm{n}=32$.

Katayama counted sixteen somatic chromosomes. Our materials showed thirty-two long chromosomes in the root-tip cells. The spindle-fiber attachment is either median or submedian (Fig. 9).

Cardiocrinum cordatum, MAKINO (Liliac.) $2 \mathrm{n}=24$.

The chromosome number of this plant was decided as twelve in haploid by TAKamine. Fig. 10 shows twenty-four long chromosomes observed by us in the root-tip cell. Four chromosomes, nearly twice as long as the others, are inserted by the spindle-fiber at the middle. The attachment of the fiber for the rest twenty chromosomes is either terminal or subterminal.

Lilium elegans, THunb. (Liliac.) $2 \mathrm{n}=24$.

Twenty-four long chromosomes were found in the root-tip cells. Four chromosomes, nearly twice as long as the rest, are attached by the spindle-fiber at the middle. The spindle-fiber attachment for the remaining twenty chromosomes is either terminal or subterminal (Fig. 11).

Lilium Maximowiczï, REGFI. (Liliac.) $\mathrm{n}=12$.

Twelve chromosomes were clearly counted in the heterotypic metaphase of the pollen mother-cell (Fig. 12).

Crocus sativa, L. (Iridac.) $2 \mathrm{n}=24$.

Twenty-four somatic chromosomes had already been counted by Himmeisaur. The same number of rod-shaped chromosomes were found by us in the root-tip cells. There are roughly three size-classes, long, medium and short, and the spindle-fiber attachment is median, terminal or subterminal (Fig. 13).

Crocus vermus, AI.L. (Iridac.) $2 \mathrm{n}=16$.

In the root-tip cells, we found sixteen chromosomes of different lengths. The spindle-fiber attachment is median, terminal or subterminal (Fig. 14).

Calanthe discolor, Lindr. (Orchidac.) $2 \mathrm{n}=40$.

Forty short rod-shaped chromosomes of various sizes were observed in the root-tip cells (Fig. 15).

Paconia albiflora, PALL. (Rananculac.) $2 \mathrm{n}=10$.

LANGLF,T decided as that its reduced and somatic chromosome number five and ten respectively. We found, in the root-tip cells ten long chromosomes, of which two are attached by the spindle-fiber at subterminal points, while perhaps four at median and another four at submedian points (Fig. 16). The mode of spindle-fiber 
insertion seems entirely similar to that observed by us for the chromosomes of Paconia Moutan, Sims. (Fig. 17).

Dentaria macrophylla, BUnGE var. dasyloba, Makrno (Crucifer.) $\mathrm{n}=8$. The haploid number of chromosomes of this plant was decided as eight. Fig. 18 shows eight spherical chromosomes in the homotypic metaphase of the pollen mother-cell.

Euonymus japonica, Thunb. (Celastrac.) $\mathrm{n}=16$.

Sixteen round chromosomes were clearly counted in the heterotypic metaphase of the pollen mother-cells (Fig. 19).

Impaticns Balsamina, L. (Balsaminac.) $\mathrm{n}=7$.

The haploid number of chromosomes of this species was determined as seven. All the chromosomes take a round shape in the heterotypic metaphase (Fig. 20).

Thea japonica, NoIs. (Theac.) $\mathrm{n}=15$.

Fifteen chromosomes of various sizes were clearly discernible in the heterotypic metaphase of the pollen mother-cell (Fig. 21). Morphologically the chromosomes of $T$. japonica are very much alike to those of $T$. sinensis.

Ternstroemia japonica, Thunb. (Theac.) $\mathrm{n}=25$.

The haploid chromosome number of this plant was decided as twenty-five. Fig. 22 shows twenty-five chromosomes in the heterotypic anaphase in the pollen mother-cell.

Cucumis Melo, L. (Cucurbitac.) $2 \mathrm{n}=24$.

The diploid number of chromosomes was reported as twenty-four by KozHukHow. The same number of very small rod-shaped chromosomes were found by us in the root-tip cells (Fig. 23).

Aster novae-angliae, L. (Composit.) $\mathrm{n}=5,2 \mathrm{n}=10$.

Carano decided upon five as the haploid number of chromosomes. We observed the same number of chromosomes in both meiotic metaphases in the pollen mother-cell. Three chromosomes are larger than the remaining two (Fig. 24, heterotypic metaphase.) Aiso ten chromosomes were found in the root-tip cells, of which six are longer than the others (Fig. 25).

Gynura bicolor, Dc. (composit.) $2 \mathrm{n}=20$.

Twenty slender chromosomes were found in the root-tip cells. The spindle-fiber attachment is either median or submedian (Fig. 26).

Ligularia tussilaginea, Makino (Composit.) $\mathfrak{n}=30$.

MiyajI describes thirty as the reduced number of chromosomes. The same number of chromosomes were observed by us in the 


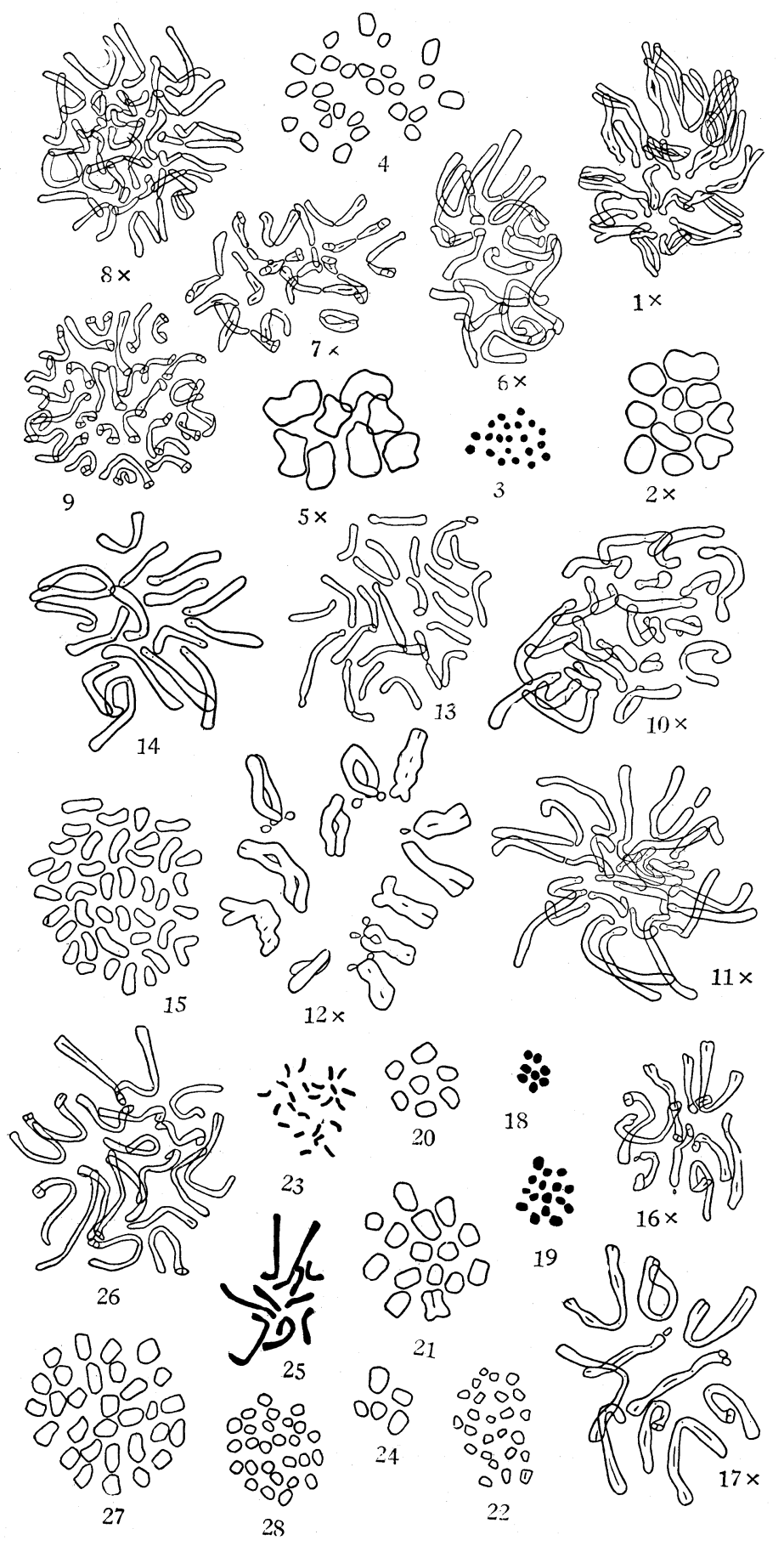


heterotypic metaphase of the pollen mother-cell (Fig. 27).

Solidago ncmoralis, AIT. (Composit.) $\mathrm{n}=27$.

We decided upon twenty-seven as the reduced chromosome number of this plant. Fig. 28 shows those chromosomes in the heterotypic metaphase of the pollen mother-cell.

Plant-Breeding Laboratory,

Kyushu Imperial University.

\section{References}

GAIser, I. O., 1930 Chromosome Numbers in Angiosperms II. Bibliographia Genetica 6.

Tischl,ER, G., 1927 Pflanzliche Chromosomen-Zahlen. Tabulae Biol. 4. 